\title{
Weather parameters vulnerability on tea production in north western Himalaya, India
}

\author{
Parmod Verma ${ }^{1}$, Ranbir Singh Rana ${ }^{2}$, Ramesh $^{2}$ and Ranu Pathania ${ }^{3}$ \\ ${ }^{1}$ Department of Tea Husbandry and Technology, CSK Himachal Pradesh Agricultural University, Palampur- \\ 176062 (H.P.), INDIA \\ ${ }^{2}$ Centre for Geo-informatics Research and Training, CSK Himachal Pradesh Agriculture University, Palampur- \\ 176062 (H.P.), INDIA \\ ${ }^{3}$ Deprtment of Agronomy, FGM, CSKHPKV, Palampur- 176062 (H.P.), INDIA \\ ${ }^{*}$ Corresponding author. E-mail: rameshhpkv@gmail.com
}

Received: October 20, 2016; Revised received: September 3, 2016; Accepted: December, 2016

\begin{abstract}
The study assessed the sensitivity of weather parameters with respect to total green leaf and two leaves and bud ( $T \& B$ ) productivity of tea crop \{Camellia sinensis (L.) Kuntze\}. The maximum temperature ranging from 20.0 to $29.0{ }^{\circ} \mathrm{C}$ during March, May, August and September showed positive relationship with values ranging from 0.26 to 3.38 and 0.22 to 3.22 for green leaf and T \& B yield, respectively. Similarly, minimum temperature ranging from 9.1 to $20.0{ }^{\circ} \mathrm{C}$ during March and July to October found positive 0.001 to 2.93 and 0.28 to 2.91 for green leaf and $T$ \& B productivity, respectively. The mean monthly rainfall amounting 52.7 to $664.7 \mathrm{~mm}$ during March, May, July to October and 52.7 to $488.4 \mathrm{~mm}$ during June, July, September and October also showed positive sensitivity with values ranging from 0.03 to 0.33 and 0.007 to 0.35 for green leaf and $T \& B$ yield, respectively. The relative humidity ranging between 41.2 to $77.3 \%$ during April to May for green leaf yield $(0.32$ to 1.71$)$ and during April to May and October for two leaf and bud yield (0.00 to 1.70) showed positive relationship. So, maximum and minimum temperature between 20.0 to $29.0^{\circ} \mathrm{C}$ and 9.1 to $20.0^{\circ} \mathrm{C}$, respectively with rainfall of 52.7 to $488.4 \mathrm{~mm}$ and relative humidity 41.2 to $77.3 \%$ are the most beneficial weather parameters for tea cultivation at Palampur conditions.
\end{abstract}

Keywords: Climate change, Productivity, Rainfall, Tea, Temperature

\section{INTRODUCTION}

Ecosystems contribute inconspicuously to human well being by supplying vital goods and services including genetic resources, habitat, maintenance and climate etc. The combined effects of climate variability and other global change drivers may impose dramatic impacts on species and ecosystems worldwide, with potentially detrimental consequences on human society. India has a varied climate and is home for many temperate and sub-tropical fruits. Tea is one of the most important plantation crops in India. In Himachal Pradesh tea cultivation is mainly practiced in Sub humid sub temperate type of climate in the mountain range of Dhauladhar of Kangra District (Bacharwar et al., 2015) (Fig. 1).

Tea is cultivated extensively in north eastern India, south India and north western India and a sizeable population is dependent on tea cultivation for livelihood, besides it's one of the major revenue earner in these areas. Also, tea cultivation forms the basic life support system in terms of direct and indirect employment generation. Tea is a crop that remains in the field for fifty plus years with economically viable produce. But the rate at which climate change triggered by global warming is taking place, the tea plant types may have to adapt to a very wide range of climate extremities. Due to its dependence on stable temperatures and consistent rainfall patterns climate change significantly affected the tea production (Anonymous, 2014).

The production of tea crop depends heavily on weather stability and therefore is alarming to the tea growers. Stephens et al. (1992) enlists temperature, saturation deficit of the air, plant and soil water deficits, rainfall and evaporation as some of the major environmental variables that affect tea (shoot) growth. The climate change challenge is compounded further by limited climate change research resources. The climate change impacts have been clearly deciphered by changes like dry and warm climate, change in snowfall and precipitation pattern (Rana et al., 2011). Climate and climate variability have a very significant effect on tea production. One of the consequences of global climate change on tea crop is the delay start of picking reducing the yield of crop and quality. Furthermore, increase in temperatures may results in drying of the soils causing reduced water content in tea, arrival of new pests and diseases which were not previously present and changes in the suitability of existing tea growing areas. Similarly, the changing rainfall patterns may 
results in uncertainty in when to apply fertilizers and may also results in soil fertility loss through erosion (Anonymous, 2014). Hence, identifying and understanding the weather parameters playing part in the growing of tea is useful in designing appropriate policy measures to enable tea producers to increase productivity and generate more income thus alleviating poverty. Thus, the present study was designed to evaluate the effect of different weather parameters on productivity of the tea yield and quality.

\section{MATERIALS AND METHODS}

The data base for three decade from 1982 to 2009 of climatic parameters recorded at CSKHPKV, Palampur about 14 hectares well maintained experimental farm situated in tea Department CSKHPKV, Palampur. The tea yield and two leaf and bud ( $\mathrm{T}$ and $\mathrm{B}$ ) of tea were taken from 14 hectare farm managed following uniform all the package and practices. The yield of tea was taken at monthly total yield and corresponding weather data was taken for the same month in order to evaluate the sensitivity of weather parameters to yield and quality parameters of tea. Amongst weather parameters rainfall total was taken whereas for Maximum, minimum temperatures, $\mathrm{RH}$ and Sunshine hours, monthly average was taken. The yield data at monthly scale was summed and climatic parameters were averaged / summed for driving the interaction impact of the climatic parameters on tea production. The detrending analysis was carried out using the following procedure. The analysis was done with the assumption that yield trend is increasing due to interventions like new varieties introductions or other agronomic practices. The analysis assesses the contribution of particular weather parameter toward the yield reduction or increase in the total period of data taken for analysis. Consequently it explains the contribution of technological trends impacts on crop yield over the years. It captures the yield variability and weather variability. The variability impacts were averaged out to draw the sensitivity of weather parameters.

The graph plotted between reference year (ref_year) and yield and decided the nature of trend line i.e. line-

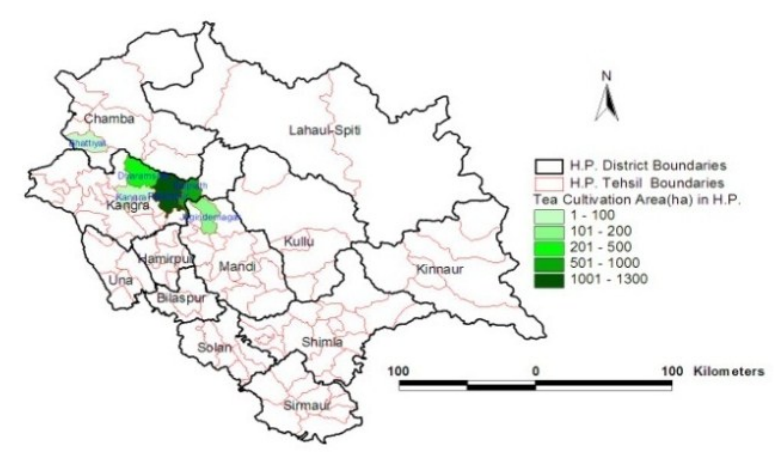

Fig.1. Tea Growing regions in Himachal Pradesh. ar / non-linear and single or double trend. From the graph fit the trend line and the value of $\mathrm{R}-$ Square was calculated. After substituting the value of Reference year as $\mathrm{x}$ value in trend line equation the value of trend predicted Yield (trend_pred_yld) obtained. The value of normalized yield deviation (nyd) $=$ (yield trend_pred_yld)/(trend_pred_yld) was calculated. The graph between ref_year and nyd was plotted which showed detrending yield series to relate to meteorological parameters. In this case yield deviation with respect to monthly rainfall deviation was taken into account to work out the sensitivity of rainfall. Monthly rainfall deviation is = (mon_tot_rf - avg_mon_tot_rf) / avg_mon_tot_rf. The graph between nyd and mon_rf_ebetween mon_rf_dev and nyd was calculated. The slope of regression equation showed the sensitivity of tea crop yield to meteorological parameter. The similar procedure was done for other weather parameters.

\section{RESULTS AND DISCUSSION}

Long term climate of the tea growing farm: Long term monthly averages of rainfall, open pan evaporation and temperatures for Palampur (1974-2009) indicated a mean annual rainfall of $2327 \mathrm{~mm}$, out of which $77 \%$ is received during South Western-monsoon (June - September), $4.5 \%$ in North Eastern-monsoon season (October-December), 8.5\% in winter season (JanuaryFebruary), and $10 \%$ in summer season (March-May). Monthly average maximum temperature of $29.9^{\circ} \mathrm{C}$ is experienced during June whereas minimum during January $\left(5.8{ }^{\circ} \mathrm{C}\right)$. Kharif and rabi season experience 22.4 and $15.4^{\circ} \mathrm{C}$ temperature in the region. The highest mean monthly open pan evaporation is observed during May $(214 \mathrm{~mm})$ and minimum of $54 \mathrm{~mm}$ during January. Similarly, relative humidity also varies between 40 to 82 percent. The minimum RH is experienced during May (40\%) and the highest during August $(82 \%)$. The available water capacity of soil was $250 \mathrm{~mm}$. The data indicated that there is soil moisture deficit during summer season from April to June (Standard week 13-25) and during post rainy season during October (Standard week 40-43). The remaining period in the year experiences soil moisture surplus of 1259 mm during 27-39 standard weeks which can be harvested and stored for subsequent irrigation of rabi crops (Fig. 2.)

Climate is a critical factor in the lives and livelihoods of the people and socioeconomic development as a whole. Climate has shown warming of 0.89 [0.69 to 1.08] ${ }^{\circ} \mathrm{C}$ over the period $1901-2012$ which is mainly attributed to anthropogenic activities (IPCC, 2013). According to IMD report 2013 highest increase in annual mean maximum temperature was for Himachal Pradesh $+0.06^{\circ} \mathrm{C}$ per year. Decreasing trend of average rainfall is observed for Himachal Pradesh (Attri and Tyagi, 2010). The rainfall trends in Himachal Pradesh 


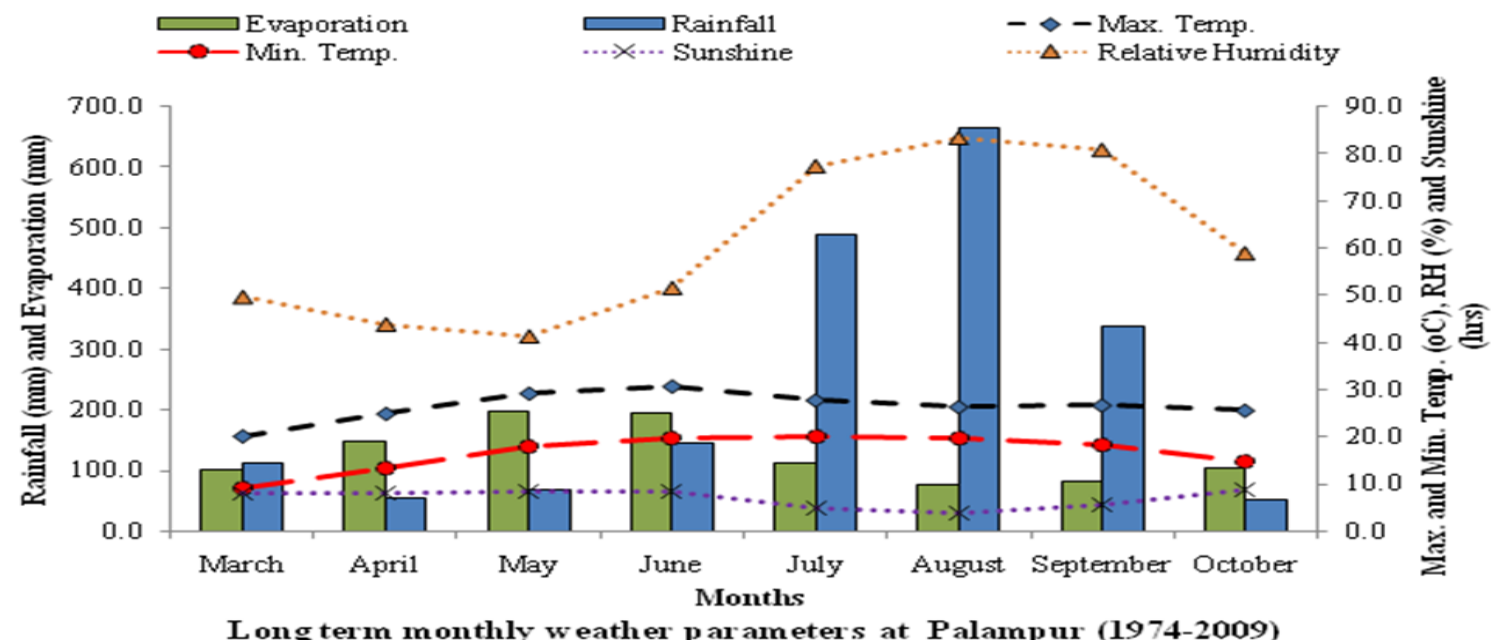

Fig. 2. Long term climatic parameters of the region.

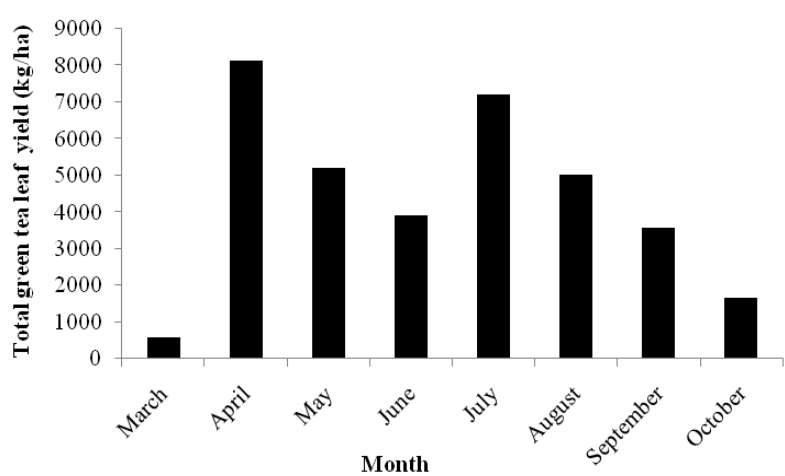

Fig. 3. Long term tea productivity in sub temperate sub humid regions of H.P.

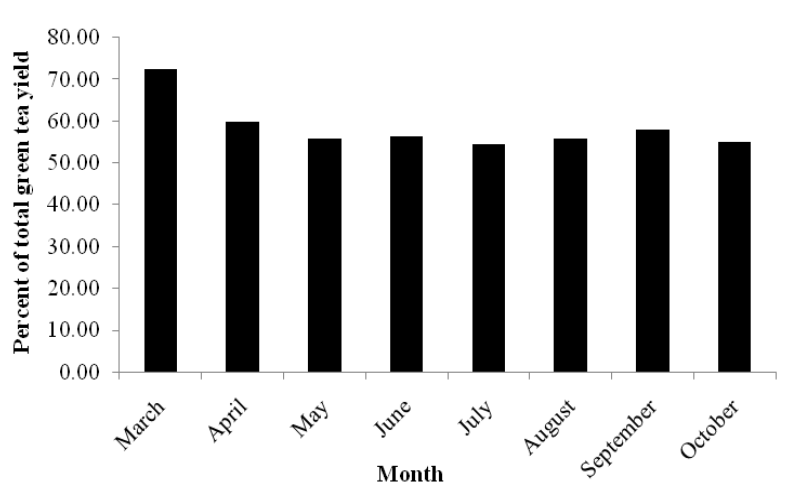

Fig. 4. Long term two leaf and bud percent of tea productivity in sub temperate sub humid regions of H.P.

Table 1. Sensitivity analysis of two leaf and bud with maximum and minimum temperatures (1983 to 2009).

\begin{tabular}{lllll} 
Month & \multicolumn{2}{c}{ Maximum temperature } & \multicolumn{2}{c}{ Minimum temperature } \\
\hline & Trends & Sensitivity & Trends & Sensitivity \\
\hline March & $\mathrm{y}=3.225 \mathrm{x}+0.025$ & +3.225 & $\mathrm{y}=2.89 \mathrm{x}+0.008$ & +2.89 \\
April & $\mathrm{y}=-0.831 \mathrm{x}-0.000$ & -0.831 & $\mathrm{y}=-0.499 \mathrm{x}-0.000$ & -0.499 \\
May & $\mathrm{y}=0.222 \mathrm{x}-0.001$ & +0.222 & $\mathrm{y}=-0.145 \mathrm{x}-0.000$ & -145 \\
June & $\mathrm{y}=-5.592 \mathrm{x}-0.01$ & -5.592 & $\mathrm{y}=-1.532 \mathrm{x}-0.009$ & -1.532 \\
July & $\mathrm{y}=-2.269 \mathrm{x}-0.006$ & -2.269 & $\mathrm{y}=0.28 \mathrm{x}-0.009$ & +0.28 \\
August & $\mathrm{y}=1.171 \mathrm{x}-0.005$ & +1.171 & $\mathrm{y}=0.587 \mathrm{x}-0.003$ & +0.587 \\
September & $\mathrm{y}=0.772 \mathrm{x}-0.005$ & +0.772 & $\mathrm{y}=2.911 \mathrm{x}-0.009$ & +2.911 \\
October & $\mathrm{y}=-0.210 \mathrm{x}-0.005$ & -0.210 & $\mathrm{y}=0.380 \mathrm{x}-0.006$ & +0.380 \\
\hline
\end{tabular}

Table 2. Sensitivity analysis of two leaf and bud with rainfall and evaporation (1983 to 2009).

\begin{tabular}{lllll}
\hline Month & \multicolumn{2}{c}{ Rainfall } & \multicolumn{2}{c}{ Evaporation } \\
\hline & Trends & Sensitivity & Trends & Sensitivity \\
\hline March & $\mathrm{y}=-0.326 \mathrm{x}+0.022$ & -0.326 & $\mathrm{y}=0.933 \mathrm{x}+0.019$ & +0.933 \\
April & $\mathrm{y}=-0.044 \mathrm{x}-0.001$ & -0.044 & $\mathrm{y}=-0.717 \mathrm{x}+0.000$ & -0.717 \\
May & $\mathrm{y}=-0.145 \mathrm{x}-0.001$ & -0.145 & $\mathrm{y}=-1.073 \mathrm{x}-0.006$ & -1.073 \\
June & $\mathrm{y}=0.351 \mathrm{x}-0.008$ & +0.351 & $\mathrm{y}=-1.160 \mathrm{x}-0.021$ & -1.160 \\
July & $\mathrm{y}=0.037 \mathrm{x}-0.009$ & +0.037 & $\mathrm{y}=-0.402 \mathrm{x}-0.008$ & -0.402 \\
August & $\mathrm{y}=-11.39 \mathrm{x}+53.39$ & -11.39 & $\mathrm{y}=16.31 \mathrm{x}+53.46$ & +16.31 \\
September & $\mathrm{y}=0.133 \mathrm{x}-0.006$ & +0.133 & $\mathrm{y}=0.052 \mathrm{x}-0.005$ & +0.052 \\
October & $\mathrm{y}=0.007 \mathrm{x}-0.005$ & +0.007 & $\mathrm{y}=-0.332 \mathrm{x}-0.004$ & -0.332 \\
\hline
\end{tabular}

based 37 stations database revealed significant decrease in rainfall amount and rainy days (Jaswal et al., 2015).
Tea productivity trends in Palampur regions: The tea productivity from a selected 14 hectare area having 
Table 3. Sensitivity analysis of two leaf and bud with sunshine and RH (1983 to 2009).

\begin{tabular}{lllll}
\hline Month & \multicolumn{2}{c}{ Sunshine Duration } & RH & Sensitivity \\
\hline & Trends & Sensitivity & Trends & -0.712 \\
March & $\mathrm{y}=1.005 \mathrm{x}+0.168$ & +1.005 & $\mathrm{y}=-0.712 \mathrm{x}+0.010$ & +0.563 \\
April & $\mathrm{y}=0.273 \mathrm{x}-0.002$ & +0.273 & $\mathrm{y}=0.563 \mathrm{x}+0.001$ & +0.000 \\
May & $\mathrm{y}=1.912 \mathrm{x}-0.010$ & +1.912 & $\mathrm{y}=0.000 \mathrm{x}+0.002$ & +1.708 \\
June & $\mathrm{y}=-0.551 \mathrm{x}-0.021$ & -0.551 & $\mathrm{y}=1.708 \mathrm{x}+0.001$ & +1.156 \\
July & $\mathrm{y}=-0.567 \mathrm{x}-0.240$ & -0.567 & $\mathrm{y}=1.156 \mathrm{x}-0.000$ & -0.521 \\
August & $\mathrm{y}=0.130 \mathrm{x}-0.006$ & +0.130 & $\mathrm{y}=-0.521 \mathrm{x}-0.000$ & -0.341 \\
September & $\mathrm{y}=-0.049 \mathrm{x}-0.005$ & -0.049 & $\mathrm{y}=-0.341 \mathrm{x}-0.001$ & +0.287 \\
October & $\mathrm{y}=-0.242 \mathrm{x}-0.006$ & -0.242 & $\mathrm{y}=0.287 \mathrm{x}+0.001$ & \\
\hline
\end{tabular}

Table 4. Sensitivity analysis of green leaf with maximum and minimum temperature (1983 to 2009).

\begin{tabular}{lllll}
\hline Month & \multicolumn{2}{c}{ Maximum temperature } & \multicolumn{2}{c}{ Minimum temperature } \\
\hline & Trends & Sensitivity & Trends & Sensitivity \\
\hline March & $\mathrm{y}=3.381 \mathrm{x}+0.028$ & +3.381 & $\mathrm{y}=2.937 \mathrm{x}+0.024$ & +2.937 \\
April & $\mathrm{y}=-0.583 \mathrm{x}-0.001$ & -0.583 & $\mathrm{y}=-0.283 \mathrm{x}-0.000$ & -0.283 \\
May & $\mathrm{y}=0.263 \mathrm{x}-0.000$ & +0.263 & $\mathrm{y}=0.001 \mathrm{x}-0.000$ & +0.001 \\
June & $\mathrm{y}=-5.733 \mathrm{x}-0.009$ & -5.733 & $\mathrm{y}=-1.446 \mathrm{x}-0.009$ & -1.446 \\
July & $\mathrm{y}=-2.833 \mathrm{x}-0.005$ & -2.833 & $\mathrm{y}=0.279 \mathrm{x}-0.009$ & +0.279 \\
August & $\mathrm{y}=0.711 \mathrm{x}-0.003$ & +0.711 & $\mathrm{y}=0.770 \mathrm{x}-0.002$ & +0.770 \\
September & $\mathrm{y}=0.657 \mathrm{x}-0.004$ & +0.657 & $\mathrm{y}=2.767 \mathrm{x}-0.008$ & +2.767 \\
October & $\mathrm{y}=-1.068 \mathrm{x}+0.002$ & -1.068 & $\mathrm{y}=0.935 \mathrm{x}-0.000$ & +0.935 \\
\hline
\end{tabular}

Table 5. Sensitivity analysis of green leaf with rainfall and evaporation (1983 to 2009).

\begin{tabular}{lllll}
\hline Month & \multicolumn{2}{c}{ Rainfall } & \multicolumn{2}{c}{ Evaporation } \\
\hline & Trends & Sensitivity & Trends & Sensitivity \\
\hline March & $\mathrm{y}=0.331 \mathrm{x}+0.024$ & +0.331 & $\mathrm{y}=1.208+0.021$ & +1.208 \\
April & $\mathrm{y}=-0.075 \mathrm{x}-0.001$ & -0.075 & $\mathrm{y}=-0.597 \mathrm{x}+0.000$ & -0.597 \\
May & $\mathrm{y}=0.186 \mathrm{x}-0.000$ & +0.186 & $\mathrm{y}=-1.145 \mathrm{x}-0.006$ & -1.145 \\
June & $\mathrm{y}=0.347 \mathrm{x}-0.034$ & -1.446 & $\mathrm{y}=-1.631 \mathrm{x}-0.022$ & -1.631 \\
July & $\mathrm{y}=0.033 \mathrm{x}-0.009$ & +0.033 & $\mathrm{y}=-0.494 \mathrm{x}-0.007$ & -0.494 \\
August & $\mathrm{y}=0.049 \mathrm{x}-0.002$ & +0.049 & $\mathrm{y}=0.165 \mathrm{x}-0.001$ & +0.165 \\
September & $\mathrm{y}=0.158-0.004$ & +0.158 & $\mathrm{y}=0.198 \mathrm{x}-0.002$ & +0.198 \\
October & $\mathrm{y}=0.036 \mathrm{x}-0.001$ & +0.036 & $\mathrm{y}=-0.000 \mathrm{x}+0.010$ & -0.000 \\
\hline
\end{tabular}

Table 6. Sensitivity analysis of green leaf with sunshine duration and RH (1983 to 2009).

\begin{tabular}{llccc}
\hline Month & \multicolumn{2}{c}{ Sunshine Duration } & RH \\
\hline & Trends & Sensitivity & Trends & Sensitivity \\
\hline March & $\mathrm{y}=1.144 \mathrm{x}+0.191$ & +1.144 & $\mathrm{y}=-0.819 \mathrm{x}+0.020$ & -0.819 \\
April & $\mathrm{y}=0.249 \mathrm{x}-0.002$ & +0.249 & $\mathrm{y}=0.508 \mathrm{x}-0.000$ & +0.508 \\
May & $\mathrm{y}=1.217 \mathrm{x}-0.376$ & +1.217 & $\mathrm{y}=0.329 \mathrm{x}-0.000$ & +0.329 \\
June & $\mathrm{y}=-0.660 \mathrm{x}+0.000$ & -0.660 & $\mathrm{y}=1.719 \mathrm{x}-0.006$ & +1.719 \\
July & $\mathrm{y}=-0.447 \mathrm{x}-0.008$ & -0.447 & $\mathrm{y}=1.610 \mathrm{x}-0.000$ & +1.610 \\
August & $\mathrm{y}=0.069 \mathrm{x}-0.003$ & +0.069 & $\mathrm{y}=-0.522 \mathrm{x}-0.001$ & -0.522 \\
September & $\mathrm{y}=-0.059 \mathrm{x}-0.004$ & -0.059 & $\mathrm{y}=-0.877 \mathrm{x}-0.002$ & -0.877 \\
October & $\mathrm{y}=-0.360 \mathrm{x}+0.001$ & -0.360 & $\mathrm{y}=0.238 \mathrm{x}+0.002$ & -0.238 \\
\hline
\end{tabular}

all common packages and practices showed yield trends in different months recorded during 1983 to 2009. The productivity during March was low to the tune of $598 \mathrm{~kg} / \mathrm{ha}$. During April it reached maximum to the tune of $8136 \mathrm{~kg} / \mathrm{ha}$. The productivity during May to October varied between 1654 to $7220 \mathrm{~kg} / \mathrm{ha} \mathrm{(Fig.} \mathrm{3).}$ The highest percent of two leaf and bud of the productivity was obtained during March (72\%) and April (60 $\%$ ) and September (58 \%) (Fig. 3). Tea productivity in past three decade showed increasing trends in the region except during May month.
Impact of weather parameters on two leaf and bud yield

Impact of temperatures and rainfall: The detrending analysis indicated highest sensitivity of maximum temperature with tea and bud (Two leaf and bud) yield. The increase in maximum temperature increased the two leaf and bud yield of tea crop during March, May, August and September (value ranging from +0.22 to +3.22) when maximum temperature varied between 20.0 to $29.0{ }^{\circ} \mathrm{C}$ in past three decade average (Table 1 ). Whereas, maximum temperatures sensitivity showed 
negative relationship during April, June, July and October $\left(24.7\right.$ to $\left.30.5^{\circ} \mathrm{C}\right)$ indicating decrease of two leaf and bud yield ( 0.21 to 5.59$)$ with increase of maximum temperature. Similar impacts were assessed / observed for minimum temperature during March and July to October corresponding to 9.1 and 14.7 to $20.0{ }^{\circ} \mathrm{C}$, respectively and sensitivity ranging from 0.28 to 2.91 with varying magnitude. The negative sensitivity was observed during April to June for two leaf and bud productivity with corresponding temperature of 13.3 to $19.5^{\circ} \mathrm{C}$. The minimum temperature during study period varied between 14.6 to $25.0{ }^{\circ} \mathrm{C}$ during all picking period in the region. The optimum temperature for tea was found to be $22^{\circ} \mathrm{C}$ for getting higher yield (Wijeratne et al., 2007). The rainfall during March $(111.4 \mathrm{~mm})$, April $(54.2 \mathrm{~mm})$, May $(69.1 \mathrm{~mm})$, and August $(664.7 \mathrm{~mm}$ caused reduction in two leaf and bud yield of tea and sensitivity ranging from 0.04 to 11.39 (Table 2). The rainfall indicated positive sensitivity during June (0.35), July (0.03), September ( 0.13$)$ and October (0.007) amounting 146.2, 488.4, 336.3 and $52.7 \mathrm{~mm}$ rainfall, respectively. The optimum rainfall for tea varied between 213 to $417 \mathrm{~mm}$ per month (Wijeratne et al., 2007). Tea yield is greatly influenced by weather and it grows well under air temperatures in the range of $18-25^{\circ} \mathrm{C}$ (Carl 1972; Watson, 1986).

Impact of evaporation: The evaporation also impacted the two leaf and bud yield. The increase in daily average evaporation during March $(3.3 \mathrm{~mm}$ per day) and August and September (2.5 to $2.8 \mathrm{~mm}$ per day) caused increase in two leaf and bud yield and sensitivity ranging from 0.052 to 16.31 (Table 2). Whereas, remaining months evaporation ranging from 3.4 to 6.5 $\mathrm{mm}$ showed reverse relationship values of sensitivity ranging from 0.33 to 1.16 .

Impact of sunshine duration and relative humidity: The sunshine sensitivity and two leaf and bud showed positive relationship during March (7.9 hrs), April (7.8 hrs), May (8.4 hrs) and August (3.6 hrs) and which indicated increase in two leaf and bud yield with sensitivity ranging from 0.273 to 1.912 with increase in sunshine hours. The June, July, September and October month reduction in sunshine duration (5.6 to 8.7 hrs) decreased the two leaf and bud yield (0.040 to 0.551 ). The relative humidity sensitivity also showed positive relationship during April to July and October (41.2 to $77.3 \%$ ) with value ranging from 0.00 to 1.70 . Whereas, March, August and September RH (49.5 to $83.3 \%$ ) increase caused reduction in two leaf and bud yield and sensitivity ranging from 0.34 to 0.71 (Table 3 ). Impact of weather parameters on green leaf yield Impact of temperature and rainfall: The green leaf bud yield and maximum temperature sensitivity showed increase in yield with increase in temperature during March $\left(20.0^{\circ} \mathrm{C}\right)$, May $\left(29.0{ }^{0} \mathrm{C}\right)$, August $\left(26.1^{\circ} \mathrm{C}\right)$ and September $\left(26.5^{\circ} \mathrm{C}\right)$ ranging from 0.26 to 3.38 when mean maximum temperature remained be- tween 14.6 to $25.0{ }^{0} \mathrm{C}$. The temperature during April $\left(24.7^{\circ} \mathrm{C}\right)$, June $\left(30.5^{\circ} \mathrm{C}\right)$, July $\left(27.5^{\circ} \mathrm{C}\right)$ and October $\left(25.4^{\circ} \mathrm{C}\right)$ indicated decrease in yield ranging from 0.58 to 5.73 with increase in temperature, however the sensitivity was observed during the month when mean temperature is $29.1^{\circ} \mathrm{C}$ in sub-humid and sub-temperate conditions of H.P. Similarly, positive sensitivity impact was observed with minimum temperature under March, May, July to October months (9.1 to $20.0{ }^{\circ} \mathrm{C}$ ) ranging from 0.001 to 2.93 (Table 4). Negative sensitivity impact was observed during April $\left(13.3{ }^{\circ} \mathrm{C}\right)$ and June $\left(19.5^{\circ} \mathrm{C}\right)$ with values 0.28 and 1.44 , respectively. The rainfall showed positive relationship during March, May, July to October indicating increasing yield with value ranging from 0.03 and 0.33 with increase in rainfall (Table 5). The mean rainfall corresponding to these months varied between 52.7 to 664.7 $\mathrm{mm}$. The decreasing trend of tea productivity in other months was due to reduction in sunshine hours. The other months mean rainfall reduction caused reduction in total green leaf yield based on past three decades data of green leaf and rainfall (Table 5). The relationship between weather and tea yield has shown that increase in rainfall and temperature increases tea yield (Devanathan, 1975; Squire, 1990) and recent observations have shown that at higher temperature regimes $\left(>25-26^{\circ} \mathrm{C}\right.$ ), the yield components of tea (shoot population density, shoot weight and shoot extension rate) tend to decrease with increasing temperatures.

Impact of evaporation: The daily average evaporation during March $(3.3 \mathrm{~mm})$ and August $(2.5 \mathrm{~mm})$ and September $(2.8 \mathrm{~mm})$ caused increase in yield $(0.16$ to $1.20)$ due to increase in evaporation where as evaporation during April $(4.9 \mathrm{~mm})$ to July $(3.6 \mathrm{~mm})$ and October $(3.4 \mathrm{~mm})$ caused reduction in yield ranging from 0.00 to 1.63 and 0.00 , respectively (Table 5). The evaporation during all picking season varied between 2.5 to $6.5 \mathrm{~mm}$.

Impact of sunshine duration and relative humidity: The sunshine duration (Hours) showed positive relationship during March (6.8 hrs), April (7.8 hrs), May ( $8.4 \mathrm{hrs)}$ and August (3.7 hrs) resulting in increase in yield ranging from 0.06 to 1.21 (Table 6). Whereas, June ( $8.4 \mathrm{hrs})$, July (4.8 hrs), September (5.6 hrs) and October $(8.7 \mathrm{hrs})$ showed negative sensitivity relationship (0.059 to 0.66$)$. The mean average sunshine duration remained between 3.7 to $8.7 \mathrm{hrs}$. Similarly, $\mathrm{RH}$ during April (43.7\%) to July (77.3\%) showed the positive relationship with green leaf yield ( 0.32 to 1.71$)$, whereas other months RH (49.5 to $83.3 \%$ ) showed reduction in yield ( 0.23 to 0.87 ) due to reduction in RH (Table 6).

\section{Conclusion}

Long term monthly averages of weather parameters for Palampur showed that maximum temperature above $24.7^{\circ} \mathrm{C}$ during dry months recorded negative sensitivity with tea production during April, June and July. 
Whereas, wettest months showed positive sensitivity above $20{ }^{\circ} \mathrm{C}$ temperature. The minimum temperature during April $\left(13.3^{\circ} \mathrm{C}\right)$ and June $\left(19.5^{\circ} \mathrm{C}\right)$ showed negative sensitivity. The monthly mean rainfall proved beneficial except April rainfall $54.2 \mathrm{~mm}$ which showed negative sensitivity due to the highest productivity month. The monthly evaporation below 84.4 showed positive relation and above that sensitivity was negative with green tea leaf productivity. Higher relative humidity $(51.5 \%)$ was not negative related to green leaf productivity except during March (49.5\%) which corresponded to the lowest yielding months. Sunshine showed inconsistent reduction after May month. Higher value of sunshine during March to May (6.8 to $8.4 \mathrm{hrs}$ ) proved to be beneficial for tea productivity. However, lower sunshine to the tune of 3.7 hours during August also proved to be beneficial for green tea productivity.

\section{REFERENCES}

Anonymous (2014). Mitigating climate change in the tea sector. International Trade Centre (ITC), Geneva. Technical paper, pp102

Attri, S.D. and Tyagi, A. (2010). Government of India Ministry of Earth Sciences Climate Profile of India Contribution to the Indian Network of Climate Change Assessment.

Bacharwar, D., Bhujade, R., Garcia, M., Konert, E. and Robinson, H. (2015). Investigating the Kangra valley tea industry. Worcester Polytechnic Institute. pp 39

Carr, M.K.V. (1972). The Climatic Requirements of the Tea Plant: A Review. Exp. L. Agri., 8(1): 1-14

Devanathan M.A.V. (1975). The quantification of the climatic constraints on plant growth. Tea Quarterly, 45: 43-72

IPCC (2013). Climate Change 2013 - The Physical Science Basis. Cambridge, University Press, U.K.

Jaswal, A.K., Bhan, S.C., Karandikar, A.S., and Gujar, M.K. (2015). Seasonal and annual rainfall in Himachal Pradesh during 1951-2005. Mausam, 66(2): 247-264

Rana, R.S., Bhagat, R.M. and Kalia, V. (2011). Impact of climate change on apple crop in Himachal Pradesh, India, J. Agromet., 13(2): 91-99

Squire, G.R. (1990). The Physiology of Tropical Crop Production, CAB International, Wallingford, Oxon, United Kingdom.

Stephens, W., Othieno, C.O. and Carr, M.K.V. (1992). Climate and Weather of Tea Research Foundation of Kenya. Agri. Meteorol., 61: 219-235

Watson, M. (1986). Soil and climatic requirements, in: Hand Book on Tea. Sivapalan P., Kulasegaram S., and Kathiravetpillai A. (eds), Tea Research Institute of Sri Lanka, pp. 3-5

Wijeratne, M.A., Anandacoomaraswamy, A., Amarathunga, M.K.S.L.D, Ratnasiri, J., Basnayake, B.R.S.B. and Kalra,. N. (2007). Assessment of impact of climate change on tea productivity of tea (Camellia sinensis L.) plantations in SriLanka. J. National Sci. Found. Sri Lanka, 35(2): 119-126 